\title{
Design of Visual Communication Media as Learning Hadith Since Early Age
}

\author{
Nadhilla Sabrina $^{1}$, Syarip Hidayat ${ }^{2}$ \\ ${ }^{1}$ Telkom University, School of Creative Industries - Visual Communication Design, Bandung, Indonesia \\ ${ }^{2}$ Telkom University, School of Creative Industries - Visual Communication Design, Bandung, Indonesia \\ nadhillasabrinaazhari@gmail.com (Nadhilla Sabrina), syarip@telkomuniversity.ac.id (Syarip Hidayat)
}

\begin{abstract}
Hadith is a knowledge about what Rasulullah SAW speaks, behave and determination. Rasulullah SAW is a perfect role model for all moslem and a main character builder. The important things to learn about hadith for preserve it are to build the islamic character especially for children as Rasulullah SAW did. Children is the next ruler in the future, good or bad the children's behaviour will impact to the future. The condition of Indonesia is really worrying now. Many people ignore the character building for the children. which known as akhlaq in Islam. Approximately $87 \%$ of Indonesian civilization are muslim but not all of them really care about it and applied it as Rasulullah did. So, it needed a media education which can gain the children's interest to learn about hadith with parent's help. The qualitative methods is used in this research with observation, interview and literature study. The media education for the children to learn hadith is illustration book. This book will presented with suitable design for children in preschool to make the study pro cess is fun and gain the children's interest.
\end{abstract}

Keywords book, education, hadith, illustration

\section{Introduction}

The case record of children as violation victims decrease as long as strict punishment for the perpetrators. On the other hand, the case records of children as the perpetrators of violence continue to increase every year. The high records of violence by children shows that the circumstances are not good. The rapid development of science and technology made children easier to access anything and it also give a negative impact, if the parents didn't monitor their children. The children that busy to play gadget made they typically spend less time in physical activities, easy to get angry, being a liar and rebellious. This is due to a lack of religious understanding.

The research show that $87 \%$ residents in Indonesia are muslims, this data result comes from the research of Badan Pusat Statistik (BPS). Unfortunately, some of them are not concerned about how to apply Islam in their daily life especially to communicate with others. So it causes many children to be the perpetrators of violence. The character of Islam known as akhlaq. Rasulullah SAW are the perfect example (uswatun hasanah) to build a good character. $\mathrm{He}$ taught us by deeds and provisions known as hadith. Hadith is the second source of Islamic law besides Al-Qur'an, it shows how to apply the law of Allah SWT contained in Al-Qur'an

\section{Main Body}

\subsection{Methods}

2.1.1 Data collecting for this research

Data collecting for this research is using literature and target observations in this case are children in kindergarten and Pembinaan Anak-Anak Salman ITB (PAS ITB). PAS ITB organizations is the place for children's coaching. PAS ITB presents mentoring activities to teach children how to apply Islam in a daily life, teaching technique used to follow the times based in hadith. Doing interview about the current problems with the psychologist, children's parent, teacher and illustrator.

\subsubsection{Analyze Method}

Analyze method using SWOT (strength, weakness, opportunity, thread). By analyzing target's activities when communicate with others, target attraction when using media for learning and interactive and effective teaching. Each data results are processed and verificated to get the conclusion. 


\subsection{Research Model}

This research is using qualitative methods. This method produces descriptive data in words. The result obtained from social real life, the relatonship between object's research with subject as a process.

\subsection{Literature Review}

\subsubsection{Educational media}

Educational media is a media which used for teaching process. This media contains message and information for teaching process. Gagne and Briggs (1975:4) said that media for learning include physical tools used to presenting the learning materials.

\subsubsection{The concept of character education and Islam}

Education in arabic known as tarbiyah and learning in arabic is ta'lim, so it will be Tarbiyah Islamiyah. Religion is a human nature. Islam is a religion that focuses on akhlaq and have a mission to make a better future. Rasulullah SAW is the first example for character building, his words, his actions all contained in hadith. For example, many ayah in Al-Qur'an and hadith that instruct us to doing good to every people especially parents.

\subsubsection{Hadith}

Hadith contain Rasulullah SAW's words and actions. Hadith is the second source of Islamic law besides Al-Qur'an, it is shows how to apply the law of Allah SWT contained in Al-Qur'an. Learning hadith is a must for all Muslims and it is used as a guide in life which is in accordance with the example of Rasulullah SAW.

\subsection{Data Analysis}

Media have to determine the media to attract target interest, so the researcher did an observation at mentoring activities in PAS ITB. The mentoring activities has a syllabus in one semester, this syllabus contains hadith about educational character for children's Islamic character building.

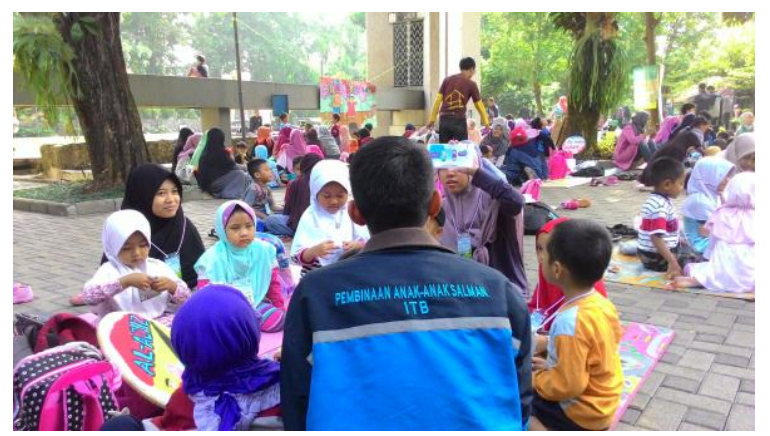

Figure 1. Learning-teaching atmosphere

Based on interview with the parents, it is shown that 95\% parents was happy with the mentoring activities in PAS ITB. The parents told that the children's behaviour has changed, they socialized, sharing with their friend and being polite with their parents. While 5\% parents are not feeling the same yet, because they just started the program for 2-3 times. Unfortunately, the media which used there is less interesting for children, especially the children's guidance book, this problem can be develop in to the media that atract the target interest and help the parents to teach the children in more expresive way.

\subsection{Result and Discussion}

The key of messages want to be delivered in the book is love fellow, trustworthy and cherish fellow. Based on observation and study the target audience, Media designed that required by target audience. The media that will develop in this research already supported by PAS ITB. The data analysis used to support the argument that children should get a educational character especially islamic character. So the children have a better behaviour as a Rasullullah SAW did.

The title of the book is "Apin Kesatria Hadits", Such title containing meaning in hadith be applied in daily life, to lead child in be and behaving good. The scenario of book illustration will be inserted hadith.

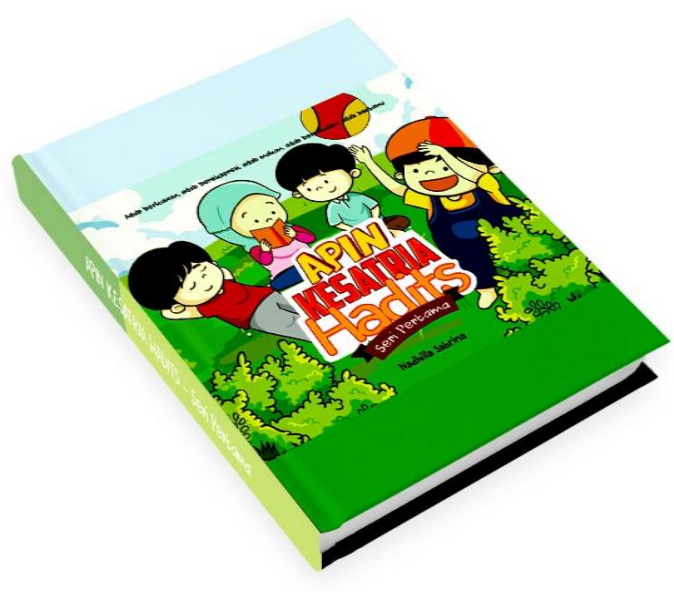

Figure 2. Cover book illustration

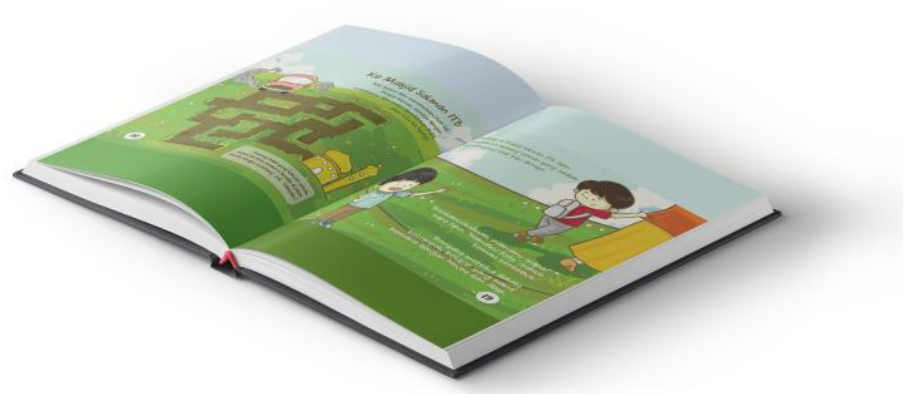

Figure 3. The contents of a book

The illustration it contains 5 matter, the courtesy of friendship, courtesy of expression, courtesy of dining, courtesy of dress and courtesy of visiting people. Delivery of any the material using illustrations and simple words, in order to help parents to be more expressive. Book illustration is also given a playground interactive so the child not get bored when the learning process. 
"Kalau begitu, Apin tahu dong apa yang akan diucapkan kepada teman-teman besok?" tanya Ayah.

"Assalamualaikum!" teriak Apin bersemangat.

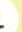

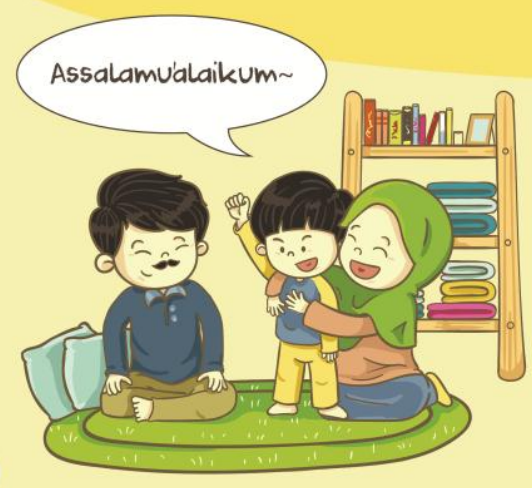

Figure 4. The contents of a book

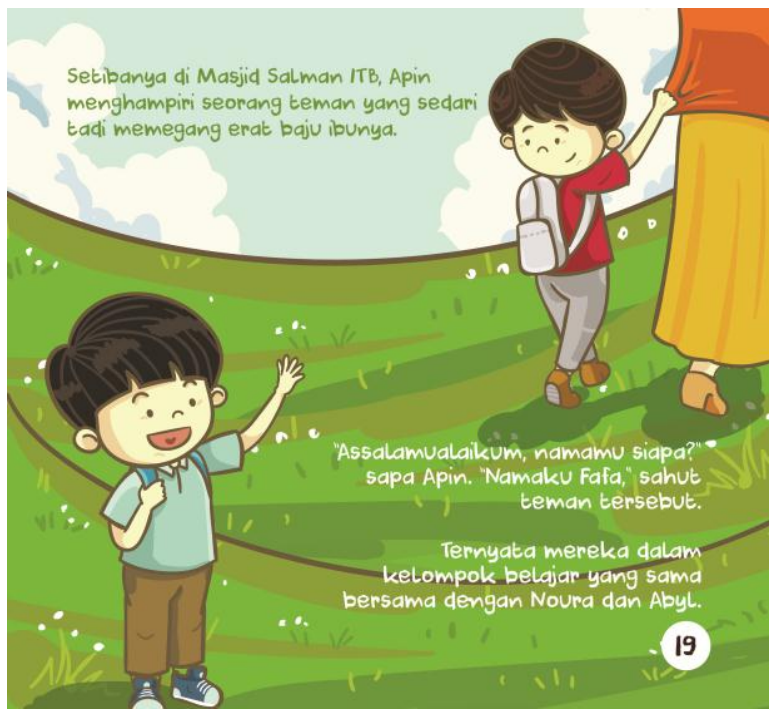

Figure 5. The contents of a book

\section{Conclusions}

This Illustration book is supporting educational media about hadith for children to Islamic character building as a Rasulullah SAW did and help to reducing the level of child cases as the main perpetrators of crime and violent behavior.

The role of parents are very impact on the children growth. Not just general knowledge, Parents should provide a religious understanding to the child as provision his life in the future.

\section{REFERENCES}

[1] Abdullah, A. S. "Teori-teori Pendidikan Berdasarkan Al-Qur'an”. Jakarta: PT Rineka Cipta, 2005.

[2] Al-Qardhawy, Y. "Islam Peradaban Masa Depan”. Jakarta: Maktabah Wahbah, 1996.

[3] Arsyad, A. "Media Pembelajaran". Depok: PT Raja Grafindo, 2013.

[4] Azhar, Y. R. "Haji dan Qurban". Bandung: Ihsan Media, 2016.

[5] Hairunnisa, A. "Smart Kids Love Hadits". Bandung: PT Grafindo Media pratama, 2013.

[6] Kusrianto, A. "Pengantar Desain Komunikasi Visual". Yogyakarta: Andi, 2009.

[7] Mashar, R. "Emosi Anak Usia Dini Dan Strategi Pengembangannya”. Jakarta: PRENADA, 2011.

[8] Morissan. "Teori Komunikasi". Bogor: Ghalia Indonesia, 2013.

[9] Novita, R. “Aku Mau Antre”. Bekasi: PT Senama Sejahtera Utama, 2016.

[10] Rahmah, N. F. "Mendesain Perilaku Anak Sejak Dini”. Jakarta: Adi Citra, 2012.

[11] Samani, M., \& Hariyanto. "Pendidikan Karakter". Bandung: PT Remaja Rosdakarya, 2012.

[12] Sihombing, D. “Tipografi Dalam Desain Grafis”. Jakarta: PT Gramedia Pustaka Utama, 2015.

[13] Soetjiningsih, C. H. "Perkembangan Anak". Jakarta: PRENADA, 2012.

[14] W, V. "Belajar Akhlak Itu Kereeen". Surakarta: Al-Qudwah Publishing, 2016.

[15] Wibowo, I. T. "Belajar Desain Grafis". Yogyakarta: NOTEBOOK, 2015. 